\title{
Urinary biomarkers of urological malignancies
}

Given our increasingly aging society, the number of patients with malignant urogenital diseases (e.g., prostate cancer, urothelial cancer, renal cell carcinoma) is increasing. Meanwhile, overdiagnosis and overtreatment are also problems, especially given the morbidities of many of the treatments available such as radical prostatectomy or radical cystectomy. In fact, as an example, the US Preventive Services Task Force has come out against PSA screening prostate cancer.

It is incumbent upon the field of Urology to pursue better and more discriminative testing for urologic malignancies. In this decade, new techniques for searching for new biomarkers have been developed, and several alternative biomarkers of prostate cancer such as urinary PCA3, serum PHI and serum 4K-score have reached the clinic. However, there are still needs for better biomarkers to detect aggressive, life-threatening prostate cancer as opposed to indolent disease. For urothelial carcinoma, urine cytology is widely used, but its sensitivity is not adequate alone. Finally, advances in new therapieshormonal therapy for prostate cancer, targeted therapy, and immune checkpoint therapy for bladder cancer, are providing new options for patients. Surrogate markers or predictive markers of response to these new treatments are necessary.

Urine is a promising source for the biomarker discovery of bladder cancer and prostate cancer. Urine after digital rectal examination is enriched with prostate cancer biomarkers, which include prostate cancer cells, DNAs, RNAs, proteins and other small molecules. Urothelial carcinoma is constantly and directly in contact with the urine and biomarkers are shed into the urine.

This series of Translational Andrology and Urology is devoted to urinary biomarkers of urological malignancies. I thank the experts in each field who contributed to this series and I hope this special series will be a useful to the readers.

\section{Acknowledgments}

Funding: None.

\section{Footnote}

Provenance and Peer Review: This article was commissioned by the editorial office, Translational Andrology and Urology for the series "Urinary Biomarkers of Urothelial Malignancies". The article did not undergo external peer review.

Conflicts of Interest: The author has completed the ICMJE uniform disclosure form (available at http://dx.doi.org/10.21037/ tau-21-109). The series "Urinary Biomarkers of Urothelial Malignancies" was commissioned by the editorial office without any funding or sponsorship. KF serves as an unpaid editorial board member of Translational Andrology and Urology from Oct 2019 to Sep 2021 and served as the unpaid Guest Editor of the series. The author has no other conflicts of interest to declare.

Ethical Statement: The author is accountable for all aspects of the work in ensuring that questions related to the accuracy or integrity of any part of the work are appropriately investigated and resolved.

Open Access Statement: This is an Open Access article distributed in accordance with the Creative Commons AttributionNonCommercial-NoDerivs 4.0 International License (CC BY-NC-ND 4.0), which permits the non-commercial replication and distribution of the article with the strict proviso that no changes or edits are made and the original work is properly cited (including links to both the formal publication through the relevant DOI and the license). See: https://creativecommons.org/ licenses/by-nc-nd/4.0/. 


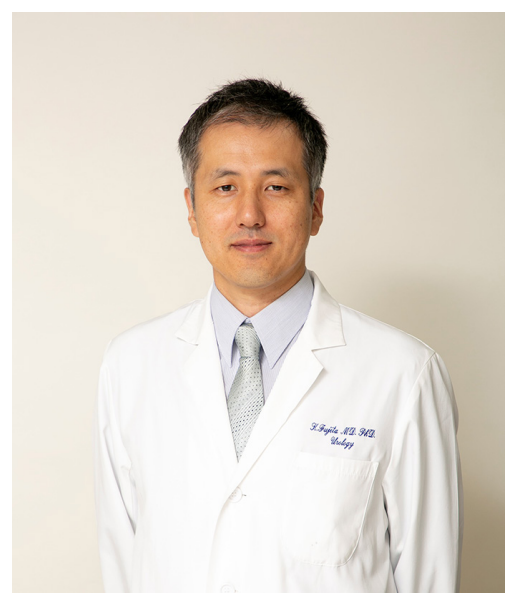

Kazutoshi Fujita

Kazutoshi Fujita Associate Professor, Department of Urology, Kindai University Faculty of Medicine, Osaka, Japan. (Email:kfujita@med.kindai.ac.jp) Submitted Feb 01, 2021. Accepted for publication Feb 24, 2021. doi: $10.21037 / \mathrm{tau}-21-109$ View this article at: http://dx.doi.org/10.21037/tau-21-109

Cite this article as: Fujita K. Urinary biomarkers of urological malignancies. Transl Androl Urol 2021;10(4):1827-1828. doi: 10.21037/tau-21-109 